\title{
The Efficacy, Safety and Side-Effect Profile of the Ketogenic Diet in the Treatment of Pediatric Super-Refractory Status Epilepticus
}

\author{
Gürkan Gürbüz $z^{1}$, Burcu Kumru², Sevinç Özsevik ${ }^{3}$, Ali Evren Bilgiç and Aycan Ünalp ${ }^{4}$ \\ ${ }^{1}$ Pediatric Neurology Department, Cengiz Gökçek Children's Hospital, Turkey \\ ${ }^{2}$ Nutrition and Dietetics Department, Cengiz Gökçek Children's Hospital, Turkey \\ ${ }^{3}$ Pediatric Intensive Care Unit, Cengiz Gökçek Children's Hospital, Turkey \\ ${ }^{4}$ Dr. Behçet UZ Children's Diseases and Surgery Teaching and Research Hospital, Health Sciences University, Turkey \\ *Corresponding author: Gürkan Gürbüz, Pediatric Neurology Department, Cengiz Gökçek Children's Hospital, Sehitkamil- \\ Gaziantep, Turkey, Tel: 9053-0696-6784
}

\begin{abstract}
Introduction: To assess patients with super-refractory status epilepticus and treated with the ketogenic diet in the pediatric intensive care unit.

Materials and methods: Six patients with super-refractory status epilepticus in the pediatric intensive care unit of Cengiz Gökçek Children's Hospital were evaluated retrospectively. Demographic characteristics, antiepileptics used, time of start and duration of ketogenic diet, and the efficacy of the diet and its side-effects were evaluated.

Results: Four of the six patients $(66.6 \%)$ were female. Patients' mean age was 2.8 years (min: 1 , max: 9 years). Four epileptic encephalopathies were determined, two Lennox-Gastaut, one WWOX encephalopathy, and one undiagnosed epileptic encephalopathy. Mean time from the start of status epilepticus to start of ketogenic diet was 13.1 days (min: 8, max: 20) and mean duration of the ketogenic diet was 4.1 months (min: 1, max: 8 ). One patient's seizures ceased, and the seizures of two other patients decreased by more than $50 \%$. One patient died from complications not associated with the ketogenic diet.

Conclusion: In this retrospective study of the efficacy of the ketogenic diet in the treatment of super-refractory epilepticus, decreases in seizure numbers of at least $50 \%$ were achieved in $50 \%$ of patients. No life-threatening complications occurred. Multi-centered, prospective studies with larger patient number will shed further light on this subject.
\end{abstract}

\section{Keywords}

Childhood, Epilepsy, Ketogenic diet, Status epilepticus

\section{Introduction}

Super-refractory status epilepticus (SRSE) is defined as persistence of seizures $24 \mathrm{~h}$ after administration of general anesthetics or as recurrence of seizures following withdrawal of general anesthetics [1]. SRSE may have a range of etiological causes and has high morbidity and mortality [2].

The ketogenic diet (KD) is a high-fat, low-carbohydrate, adequate-protein diet. It has been used in the treatment of drug-resistant epilepsy in adults and children for many years [3]. The few studies of its use in childhood status epilepticus (SE) and SRSE have involved low patient numbers [4-6]. This study focuses on whether KD is a safe and effective therapeutic method in SRSE. The efficacy and safety of KD was evaluated in six patients meeting SRSE criteria in our center.

\section{Materials and Methods}

Six patients aged 1-18 months admitted to the Gaziantep Cengiz Gökçek Children's Hospital pediatric intensive care unit with a diagnosis of SRSE were evaluated retrospectively. KD was initiated at a 4:1 ratio to all patients with persisting seizures despite conventional antiepileptic therapy and general anesthetics. Before starting KD, all patients underwent basic tests to eliminate the contraindications for KD contraindications (Table 1). KD was administered to all patients in four total doses via nasogastric tube. In

Citation: Gürbüz G, Kumru B, Özsevik S, Bilgiç AE, Ünalp A (2019) The Efficacy, Safety and Side-Effect Profile of the Ketogenic Diet in the Treatment of Pediatric Super-Refractory Status Epilepticus. J Nutri Med Diet Care 5:041. doi.org/10.23937/2572-3278.1510041

Accepted: October 14, 2019: Published: October 16, 2019

Copyright: (c) 2019 Gürbüz G, et al. This is an open-access article distributed under the terms of the Creative Commons Attribution License, which permits unrestricted use, distribution, and reproduction in any medium, provided the original author and source are credited. 
contrast to the KD protocol applied in refractory epilepsy, KD was planned in the form of four KD meals from the first day, rather than increasing the number of KD meals by one each day. No patient was fasted before the diet. The seizure burden of the patients and the decrease in the number of seizures were calculated starting from the first day of hospitalization with the diagnosis of status epilepticus until discharge, regardless of whether the patients had previous ep-

Table 1: Pre-KD basal laboratory tests.

\section{Complete blood count}

Electrolytes, bicarbonate, total protein, calcium, magnesium, selenium, phosphate

Plasma amino acids

Urine amino acids

Liver and kidney function tests

Urine organic acids

Fasting serum lipids

Serum free carnitine profile

Complete urinalysis

Urine $\mathrm{Ca} /$ creatinine ratio ilepsy or not. In addition to patients' demographic characteristics, we also evaluated on which day of SE the diet was started, when ketosis began, antiepileptic drugs used before KD, side-effects, time to end of SE, and neurological status at discharge. Since beta hydroxybutyrate could not studied in our health center laboratory, the ketosis status of the patients was evaluated with urine ketone three times a day. Antiepileptics were modified from suspension to tablet form, all intravenous therapies were administered with non-glucose-containing fluid, and all exogenous glucose sources were eliminated. All patients were started on oral multivitamins, and children with selenium and carnitine deficiency received appropriate support. All data were obtained from patient records. Due to the lack of a long-term electroencephalography (EEG) monitoring unit in our hospital, daily conventional 30 minute electroencephalography findings were evaluated by a pediatric neurologist.

\section{Results}

Six patients were included in the study. Patients' demographic characteristics are summarized in (Ta-

Table 2: Patient characteristics and treatments received before initiation of ketogenic diet.

\begin{tabular}{|c|c|c|c|c|c|c|c|c|c|}
\hline Patient & Age & Sex & Diagnosis & EEG & $\begin{array}{l}\text { Previously } \\
\text { epilepsy } \\
\text { history }\end{array}$ & $\begin{array}{l}\text { Duration of } \\
\text { SE before } \\
\text { KD (days) }\end{array}$ & $\begin{array}{l}\text { Number } \\
\text { of AEDs } \\
\text { before SE }\end{array}$ & $\begin{array}{l}\text { Steroid } \\
\text { or ACTH } \\
\text { before KD }\end{array}$ & $\begin{array}{l}\text { IVIG } \\
\text { before } \\
\text { KD }\end{array}$ \\
\hline 1 & 3 & Female & LGS & Gen. SE & Yes & 11 & $\begin{array}{l}8 \\
\text { LEV, VPA, } \\
\text { PHT, CZP, } \\
\text { CLB, PB, } \\
\text { TPN, MDZ }\end{array}$ & Yes & No \\
\hline 2 & 2 & Female & $\begin{array}{l}\text { Cerebral palsy, } \\
\text { refractory epilepsy }\end{array}$ & Focal SE & Yes & 20 & $\begin{array}{l}6 \\
\text { LEV, VPA, } \\
\text { PHT, CBZ, } \\
\text { CLB, PB, } \\
\text { TPN, MDZ }\end{array}$ & No & Yes \\
\hline 3 & 3 & Female & LGS & Gen. SE & Yes & 15 & $\begin{array}{l}6 \\
\text { LEV, VPA, } \\
\text { PHT, TPM, } \\
\text { PB, TPN }\end{array}$ & No & Yes \\
\hline 4 & 9 & Female & $\begin{array}{l}\text { Epileptic } \\
\text { encephalopathy } \\
\text { (of unknown } \\
\text { cause, } \\
\text { unclassifiable) }\end{array}$ & Jen. SE & Yes & 13 & $\begin{array}{l}8 \\
\text { LEV, VPA, } \\
\text { PHT, CLB, } \\
\text { PB, TPN, } \\
\text { MDZ, PPF }\end{array}$ & Yes & Yes \\
\hline 5 & 5 & Male & HSV encephalitis & Focal SE & No & 12 & $\begin{array}{l}5 \\
\text { LEV, VPA, } \\
\text { PHT, CBZ, } \\
\text { TPN }\end{array}$ & No & No \\
\hline 6 & 1 & Male & $\begin{array}{l}\text { Epileptic } \\
\text { encephalopathy } \\
\text { (WOXX mutation) }\end{array}$ & Jen. SE & Yes & 8 & $\begin{array}{l}4 \\
\text { LEV, PHT, } \\
\text { PB, TPN }\end{array}$ & No & No \\
\hline
\end{tabular}

AED: Antiepileptic Drug; CBZ: Carbamazepine; CLB: Clobazam; CZP: Clonazepam; EEG: Electroencephalography; Focal SE: Focal Status Epilepticus; Gen. SE: Generalized Status Epilepticus; HSV: Herpes Simplex Virus; IVIG: Intravenous Immunoglobulin; KD: Ketogenic Diet; LGS: Lennox-Gastaut Syndrome; LEV: Levetiracetam; MDZ: Midazolam; PHT: Phenytoin; PB: Phenobarbital; TPN: Thiopental; TPM: Topiramate; VPA: Valproic Acid. 
Table 3: Patients' ketogenic diet responses and side-effects.

\begin{tabular}{|c|c|c|c|c|c|c|c|c|}
\hline Patient & $\begin{array}{l}\text { KD } \\
\text { ratio }\end{array}$ & $\begin{array}{l}\text { Time to } \\
\text { ketosis } \\
\text { (days) }\end{array}$ & $\begin{array}{l}\text { Time } \\
\text { to end } \\
\text { of SE } \\
\text { (days) }\end{array}$ & $\begin{array}{l}\text { Decrease } \\
\text { in seizure } \\
\text { frequency } \\
(\%)\end{array}$ & $\begin{array}{l}\text { Duration of } \\
\text { KD (months) }\end{array}$ & Side-effects & $\begin{array}{l}\text { Duration of } \\
\text { hospitalization } \\
\text { (days) }\end{array}$ & $\begin{array}{l}\text { Status at } \\
\text { discharge }\end{array}$ \\
\hline 1 & $4: 1$ & 3 & 4 & 100 & 8 (continuing) & - & 40 & Rehab. \\
\hline 2 & $3: 1$ & 5 & - & 0 & 1 & $\begin{array}{l}\text { Hyperlipidemia, } \\
\text { GER }\end{array}$ & 52 & Deceased \\
\hline 3 & $4: 1$ & 2 & 7 & $>50$ & 8 (continuing) & GER & 38 & Rehab. \\
\hline 4 & $3: 1$ & 7 & 18 & 0 & 2 & $\begin{array}{l}\text { Vomiting, weight } \\
\text { loss, increase in } \\
\text { seizures. }\end{array}$ & 48 & Rehab. \\
\hline 5 & $4: 1$ & 4 & 5 & $>50$ & 3 (continuing) & - & 34 & Rehab. \\
\hline 6 & $4: 1$ & 2 & 4 & $<50$ & 3 & Weight loss & 24 & Rehab. \\
\hline
\end{tabular}

KD: Ketogenic Diet; GER: Gastroesophageal Reflux; Rehab: Rehabilitation Process.

ble 2). Patients' ages ranged between one and nine years, with a mean age of 2.8 years. Focal SE was present in two patients, and five had a previous history of seizure. The patients constituted a heterogeneous etiological group. Lennox-Gastaut syndrome was determined in two patients, drug-resistant epilepsy with cerebral palsy in one, herpes simplex virus encephalopathy in one, and previously diagnosed epileptic encephalopathy with WWOX gene positivity in one. Non-lesional epileptic encephalopathy (unclassified) not diagnosed genetically was present in one patient. Mean time from onset of SE to initiation of KD diet was 13.1 days (min: 8, max: 20), and mean duration of KD was 4.1 months ( $\min : 1$, max: 8). Since inflammatory processes could not be excluded before KD, three patients had received intravenous immunoglobulin, and two received pulse methylprednisolone or adrenocorticopic hormone (ACTH). A conventional SE protocol was applied to all patients, who received at least four antiepileptic drugs before start of KD. Four patients tolerated KD at a $4: 1$ ratio, while the ratio was reduced to $3: 1$ in two cases due to side-effects. No life-threatening complication was observed in any patient (Table 3). Side-effects included hyperlipidemia in one patient, gastro-esophageal reflux in two, weight loss and vomiting in two, and increased seizure numbers in one. One patient's seizures resolved entirely and seizure free until fourth day of the KD. Seizure burden of two other patients decreased by more than $50 \%$. Seizure numbers decreased by less than $50 \%$ or else increased in the other three patients. One patient died due to infection, while the other subjects were enrolled in rehabilitation programs and discharged.

\section{Discussion}

With our experience from this small patient series, we concluded that $K D$ is an effective and safe therapeutic option in SRSE. KD is recommended in SRSE by several centers, although previous studies in SRSE have involved low patient numbers $[7,8]$. One study of the efficacy of KD in febrile illness-related epileptic encephalopathy (FIRES) observed that seizures ceased on the fourth day of KD therapy in seven out of 10 patients [3]. FIRES was not present in any of our patients. One review study involving children and adults reported that 25 out of 32 patients started on KD due to SE were completely seizure-free [3]. In our study, the figure was significantly lower, at $1 / 6$ (16.6\%). We attribute this to our study group consisting entirely of children. The total prevalence of seizures in previous studies of SRSE ranges between $40 \%$ and $100 \%$, but is lower in the pediatric age group $[4,7,9-11]$.

The youngest patient receiving KD in the literature was a nine-week-old subject with malignant migratory partial epilepsy, in whom a decrease in seizures of more than $50 \%$ was reported with KD [12]. The youngest child in our study was a one-year-old patient with WWOX encephalopathy. The manifestation of SE ceased in this patient on Day 4 of KD, while daily seizure burden decreased by less than $50 \%$ compared to baseline.

Prolongation of SE has been proved to increase morbidity and mortality in experimental studies [13]. While early seizure control was established with early administration of phenytoin and diazepam in one animal study, these had no effect when applied later. This is due to functional and structural changes in GABA-A receptors [14-16]. Since these changes also reduce the effect of antiepileptic drugs in the central nervous system, antiepileptics have a limited effect in SRSE. In the light of these findings, prompt initiation of KD in SRSE should be considered since this will reduce morbidity and mortality. The antiepileptic function of KD is thought to be potentially associated with its anti-inflammatory effect and neurotransmitter modulation [17].

Due to the difficulty in administering a high fat ratio intravenously, and since it can cause alterations in the metabolism of most antiepileptic drugs metabolized in the liver, we elected to administer KD to all patients by 
enteral nasogastric tube, rather than parenterally. As also applied in the previous literature, patients were started on oral nutrition after extubation, a ketogenic menu also began being prepared after discharge, and nutrition was continued in this manner [6].

Limitations of this study include its retrospective nature, the small patient group, and that other antiepileptics continued to be administered during application of the KD. The effect of antiepileptic drugs, intravenous immunoglobulins and steroids could not therefore be excluded in the decrease in or cessation of seizures. Although, no antiepileptic drugs or immunological agents added after initiation of KD.

However, due to the low number of studies showing the efficacy of KD in childhood SRSE worldwide and the fact that we encountered no such publication from Turkey, we think that our study will make a significant contribution to the literature.

\section{Conclusion}

In this retrospective study of the efficacy of KD in SRSE, seizure burden decreased by more than $50 \%$ in $50 \%$ of patients. This shows that KD is an effective therapeutic method in SRSE. No life-threatening complications were observed. Multi-centered, prospective studies with larger patient number will shed further light on effectiveness of KD in SRSE in childhood.

\section{References}

1. Ferlisi M, Shorvon S (2012) The outcome of therapies in refractory and super-refractory convulsive status epilepticus and recommendations for therapy. Brain 135: 2314- 2328.

2. Holtkamp M, Othman J, Buchheim K, Meierkord H (2005) Predictors and prognosis of refractory status epilepticus treated in a neurological intensive care unit. J Neurol Neurosurg Psychiatr 76: 534-539.

3. Kossoff EH, Nabbout R (2013) Use of dietary therapy for status epilepticus J Child Neurol 28: 1049-1051.

4. Nabbout R, Mazzuca M, Hubert P, Peudennier S, Allaire $C$ et al. (2010) Efficacy of ketogenic diet in severe refractory status epilepticus initiating fever induced refractory epileptic encephalopathy in school age children (FIRES). Epilepsia 51: 2033-2037.

5. O'Connor SE, Ream MA, Richardson C, Mikati MA,
Trescher WH, et al. (2014) The ketogenic diet for the treatment of pediatric status epilepticus. Pediatr Neurol 50: 101103.

6. Vaccarezza M, Silva W, Maxit C, Agosta G (2012) Super-refractory status epilepticus: Treatment with ketogenic diet in pediatrics Rev Neurol 55: 20-25.

7. Bodenant M, Moreau C, Sejourné C, Auvin S, Delval A, et al. (2008) Interest of the ketogenic diet in a refractory status epilepticus in adults Rev Neurol (Paris) 164: 194-199.

8. Caraballo RH, Reyes G, Avaria MF, Buompadre MC, Gonzalez M, et al. (2013) Febrile infection-related epilepsy syndrome: A study of 12 patients. Seizure 22: 553-559.

9. Villeneuve N, Pinton F, Bahi-Buisson N, Dulac O, Chiron C, et al. (2009) The ketogenic diet improves recently worsened focal epilepsy. Dev Med Child Neurol 51: 276-281.

10. Kumada T, Miyajima T, Kimura N, Saito K, Shimomura $H$, et al. (2010) Modified Atkins diet for the treatment of nonconvulsive status epilepticus in children. J Child Neurol 25: 485-489.

11. Nam SH, Lee BL, Lee CG, Yu HJ, Joo EY, et al. (2012) The role of ketogenic diet in the treatment of refractory status epilepticus. Epileptic Disord 14: 438-441.

12. Cobo NH, Sankar R, Murata KK, Sewak SL, Kezele MA, et al. (2015) The ketogenic diet as broad-spectrum treatment for super-refractory pediatric status epilepticus: Challenges in implementation in the pediatric and neonatal intensive care units. J Child Neurol 30: 259-266.

13. Mazarati AM, Baldwin RA, Sankar R, Wasterlain CG (1998) Time-dependent decrease in the effectiveness of antiepileptic drugs during the course of self-sustaining status epilepticus. Brain Res 814: 179-185.

14. Kapur J, Lothman EW, DeLorenzo RJ (1994) Loss of GABAA receptors during partial status epilepticus. Neurology 44: 2407-2408.

15. Kapur J, Macdonald RL (1997) Rapid seizure-induced reduction of benzodiazepine and $\mathrm{Zn} 2+$ sensitivity of hippocampal dentate granule cell GABAA receptors. J Neurosci 17: 7532-7540.

16. Jones DM, Esmaeil N, Maren S, Macdonald RL (2002) Characterization of pharmacoresistance to benzodiazepines in the rat Li-pilocarpine model of status epilepticus. Epilepsy Res 50: 301-312.

17. Jeong EA, Jeon BT, Shin HJ, Kim N, Lee DH, et al. (2011) Ketogenic diet-induced peroxisome proliferator-activated receptor-g activation decreases neuroinflammation in the mouse hippocampus after kainic acid-induced seizures. Exp Neurol 232: 195-202. 